\begin{tabular}{ccl}
\hline+5 Jurnal Teknologi Kimia Unimal & $\begin{array}{l}\text { Jurnal } \\
\text { Teknologi }\end{array}$ \\
homepage jurnal: https://ojs.unimal.ac.id/jtk/index & $\begin{array}{l}\text { Kimia } \\
\text { Unimal }\end{array}$
\end{tabular}

\title{
PENGARUH SUHU, PERSENTASE AIR, DAN LAMA PENYIMPANAN TERHADAP PERSENTASE KENAIKAN ASAM LEMAK BEBAS (ALB) PADA CRUDE PALM OIL (CPO)
}

\author{
Deifa Nurfiqih , Lukman Hakim*, Muhammad \\ Jurusan Teknik Kimia, Fakultas Teknik, Universitas Malikussaleh \\ Kampus Utama Cot Teungku Nie Reuleut, Muara Batu, Aceh Utara - 24355 \\ Korespondensi: 085296148295, Lukman.hakim@unimal.ac.id
}

\begin{abstract}
Abstrak
Asam lemak merupakan hasil hidrolisa dari minyak sawit, minyak sawit terdapat berbagai macam asam lemak. Dalam perhitungan asam lemak yang digunakan adalah asam palmitate. Selain proses hidrolisa, proses oksidasi juga dapat terjadi karena kenaikan asam lemak bebas. Air dapat menguap pada minyak sawit jika dipanaskan pada suhu $150^{\circ} \mathrm{C}$, karena itu pemanasan perlu dilakukan untuk mengurangi pertambahan asam lemak bebas pada CPO dengan proses hidrolisa. Penelitian ini bertujuan untuk membandingkan antara lama penyimpanan, suhu pemanasan dan persentase air didalam minyak kelapa sawit. Metode yang digunakan yaitu persiapan bahan baku dan tahap pengujian. Untuk hasil dalam analisa asam lemak bebas dan kadar air yang paling bagus yaitu waktu penyimpanan selama 8 jam pada suhu $60^{\circ} \mathrm{C}$ dengan nilai asam lemak bebas (ALB) yaitu 2,5\% dan kadar airnya dengan nilai 0,38\%. Hasil analisa yang dihasilkan persentase air sangat berpengaruh besar dalam kenaikan asam lemak bebas (ALB) dibandingkan dengan suhu pemanasan dalam minyak kelapa sawit. Diharapkan untuk penelitian selanjutnya dapat dilakukan variasi waktu pemanasan agar memperoleh hasil yang sesuai dengan standar mutu.
\end{abstract}

Kata kunci: Asam lemak bebas (ALB), kadar air, suhu pemanasan, lama penyimpanan, persentase air.

\section{Pendahuluan}

Kelapa sawit adalah tumbuhan industri/ perkebunan yang berguna sebagai penghasil minyak masak, minyak industri, maupun bahan bakar. Pohon kelapa sawit terdiri dari dua spesies yaitu elaeis guineensis dan elaeis oleifera yang digunakan untuk pertanian komersil dalam pengeluaran minyak sawit (Ihsan \& Adi, 2017). Pohon kelapa sawit elaeis guineensis, berasal dari Afrika Barat diantara Angola dan Gambia, pohon kelapa sawit elaeis oleifera, berasal dari Amerika Tengah dan Amerika Selatan. Kelapa sawit menjadi populer setelah 
revolusi industri pada akhir abad ke-19 yang menyebabkan tingginya permintaan minyak nabati untuk bahan pangan dan industri sabun (Lembar, 2021).

Permasalahan yang sering terjadi pada pabrik CPO adalah penurunan mutu CPO yang disebabkan oleh peningkatan kadar asam lemak bebas (ALB). Kadar asam lemak bebas yang tinggi menyebabkan ketengikan, perubahan rasa dan warna pada minyak. Salah satu faktor penyebab meningkatnya kadar asam lemak bebas pada minyak adalah kerusakan morfologi dan mikroorganisme pada buah kelapa sawit. Kerusakan pada buah kelapa sawit dipicu oleh proses pemanenan, pengangkutan hingga penimbunan buah kelapa sawit yang dilakukan secara sembrono. Buah kelapa sawit yang mengalami kerusakan morfologi dan ditempatkan dilingkungan yang kotor serta lembab sangat cocok tempat pertumbuhan mikroorganisme. Aktivitas mikroorganisme pada buah kelapa sawit sangat berpengaruh terhadap peningkatan kadar ALB minyak. Mikroorganisme menghasilkan enzim lipase yang berfungsi sebagai biokatalisator reaksi hidrolisis minyak menghasilkan gliserol dan asam lemak bebas (Ayu et al., 2020).

Standar mutu CPO diatur melalui badan standar Indonesia yang dimuat dalam SNI-01-2901-2006. Dalam standar tersebut ditetapkan kadar air dan kadar kotoran adalah 0,5\% sedangkan kadar ALB 5,0\% (Dikti, 2016).

Kadar air adalah bahan yang menguap pada pemanasan dengan suhu dan waktu tertentu. Kadar air merupakan salah satu parameter untuk menentukan tingkat kemurnian minyak atau lemak dan berhubungan dengan daya simpannya, bau dan rasa. Kadar air sangat menentukan kualitas dari minyak atau lemak yang dihasilkan (Nasikin \& Nurhayanti, n.d.). Kadar air juga berperan dalam proses oksidasi maupun hidrolisis minyak yang akhirnya dapat menyebabkan ketengikan. Semakin tinggi kadar air, minyak akan semakin cepat tengik (Toeti Herati Noerhadi, 1984).

Berdasarkan penelitian sebelumnya yang telah dilakukan oleh Abdullah Derlen mengenai Pengaruh Suhu dan Lama Pemanasan Terhadap Kerusakan Minyak Kelapa mengatakan bahwa angka asam menurun dengan naiknya suhu pemanasan dan mengalami kenaikan angka asam dalam waktu yang lama selama pemanasan. 
Berdasarkan uraian diatas, masalah kadar asam lemak bebas yang terkandung dalam minyak CPO menjadi permasalahan yang besar di industriindustri pabrik kelapa sawit selama ini. Besarnya asam lemak bebas (ALB) dalam minyak ditunjukan dengan nilai \% ALB. \% ALB yang tinggi mengindikasikan bahwa asam lemak bebas (ALB) yang ada di dalam minyak CPO juga tinggi sehingga kualitas minyak justru semakin rendah. Oleh karena itu, dalam penelitian dilakukan analisa pengaruh suhu, persentase air dan lama penyimpanan Crude palm oil (CPO) terhadap persentase kenaikan asam lemak bebas (ALB).

\section{Bahan dan Metode}

\subsection{Bahan dan Peralatan}

Bahan dan peralatan yang diperlukan dalam penelitian ini antara lain adalah minyak kelapa sawit (CPO) $5 \mathrm{gr}$, N-Heksan $5 \mathrm{ml}$, alcohol $10 \mathrm{ml}$, indicator phenolphthalein 5 tetes, $\mathrm{KOH}$. Corong kecil, Erlenmeyer, pipet tetes, buret, gelas ukur, oven, cawan porselin, neraca analitik, dan desikator.

\section{$2.2 \quad$ Metode}

\subsubsection{Prosedur Persiapan Bahan Analisa}

Langkah-langkah yang dilakukan pada tahap proses persiapan bahan analisa yaitu, yang pertama minyak kelapa sawit (CPO) yang sudah diambil dari pabrik dianalisa persentase asam lemak bebasnya terlebih dahulu, kemudian disimpan dalam waktu 8 jam dengan suhu $50^{\circ} \mathrm{C}$, lalu analisa kadar asam lemak bebas (ALB) kembali, hasil analisa persentase asam lemak bebas ditambahkan air kembali sampai mencapai persentase air sebanyak 0,35\%, analisa kembali persentase asam lemak bebas yang sudah ditambahkan air dan perlakukan yang sama dengan menggantikan suhu, lama penyimpanan dan persentase air.

\subsubsection{Tahap Analisa Minyak Kelapa Sawit}

Analisa penurunan kadar ALB pada kelapa sawit (CPO) dilakukan dengan beberapa parameter yang diamati diantaranya: Analisa persentase asam lemak bebas (\%) dan analisa kadar air. 


\section{Analisa Kadar Asam Lemak Bebas (\%)}

Analisa asam lemak bebas (ALB) pada minyak Crude Palm Oil (CPO) yang akan dilakukan dengan menggunakan metode titrasi asam basa yaitu yang pertama minyak kelapa sawit (CPO) sebanyak 5 gr dimasukkan kedalam erlenmeyer, kemudian tambahkan alkohol sebanyak $10 \mathrm{ml}$ kedalam Erlenmeyer, tambahkan N-Heksan sebanyak $5 \mathrm{ml}$ kedalam Erlenmeyer, ditambahkan indicator phenolphetalin sebanyak 5 tetes, dititrasi dengan $\mathrm{KOH} 0,1 \mathrm{~N}$ sampai berubah warna, catat volume larutan $\mathrm{KOH}$ yang terpakai, kemudian hitung kadar asam lemak bebasnya. Kadar asam lemak bebas dihitung dengan menggunakan persamaan:

$\%$ kadar asam lemak bebas $=\frac{\text { Volume titran } x \text { normalitas } x B M C P O}{\text { Berat sampel } x 1000} \times 100$

\section{Analisa Kadar Air (\%)}

Analisa kadar air pada minyak Crude Palm Oil (CPO) yang akan dilakukan dengan menggunakan metode gravimetri (Kadar et al., 2009). Persiapan yang pertama yaitu timbang cawan porselin kosong, kemudian tambah sampel sebanyak 5 gr kedalam cawan, keringkan dalam oven selama 3 jam pada suhu $105^{\circ} \mathrm{C}$, dinginkan dalam desikator selama 10 menit, timbang cawan yang berisi sampel sampai mencapai bobot konstan, kemudian hitung kadar airnya. Kadar air dihitung dengan menggunakan persamaan:

Kadar air $\%=\frac{(\text { m.cawan }+ \text { m.sampelsebelumdioven })-(\text { m.cawan }+ \text { m.cawansesudahdioven })}{\text { m.sampel }} \times 100$

\section{Hasil dan Diskusi}

Asam lemak merupakan hasil hidrolisa dari minyak sawit. Didalam minyak sawit terdapat berbagai macam asam lemak, tetapi didalam perhitungan, asam lemak yang digunakan adalah asam palmitat. Karena kandungan asam lemak yang terbanyak didalam minyak sawit adalah asam palmitat. Setelah diperoleh asam lemak kemudian dilakukan analisa kadar asam lemak, analisa densitas, bilangan peroksida dan kadar air (Toeti Herati Noerhadi, 1984).

Asam lemak bebas dalam konsentrasi tinggi yang terikut dalam minyak sawit sangat merugikan. Kenaikan asam lemak bebas ini disebabkan adanya reaksi hidrolisa pada minyak. Hasil reaksi hidrolisa minyak sawit adalah gliserol 
asam lemak bebas. Reaksi ini dapat dipercepat dengan adanya faktor-faktor panas, air, keasaman dan katalis (enzim).

Semakin lama reaksi berlangsung maka semakin banyak kadar asam lemak bebas (ALB) yang terbentuk (Derlean, 2009). Oleh sebab itu dilakukannya penelitian dengan variasi suhu, waktu dan persentase air, maka dapat dilihat dibawah ini.

\subsection{Pengaruh Suhu Pemanasan, Waktu Pemanasan, dan Persentase Air Terhadap Asam Lemak Bebas (ALB)}

Asam lemak bebas (ALB) pada minyak Crude Palm Oil (CPO) yang dilakukan dengan menggunakan metode titrasi asam basa, sedangkan penentuan kadar air dilakukan dengan menggunakan metode gravimetri (Kadar et al., 2009). Hasil penelitian terhadap asam lemak bebas (ALB) yang dihasilkan dapat dilihat pada Gambar 3.1 (a),(b) dan (c).

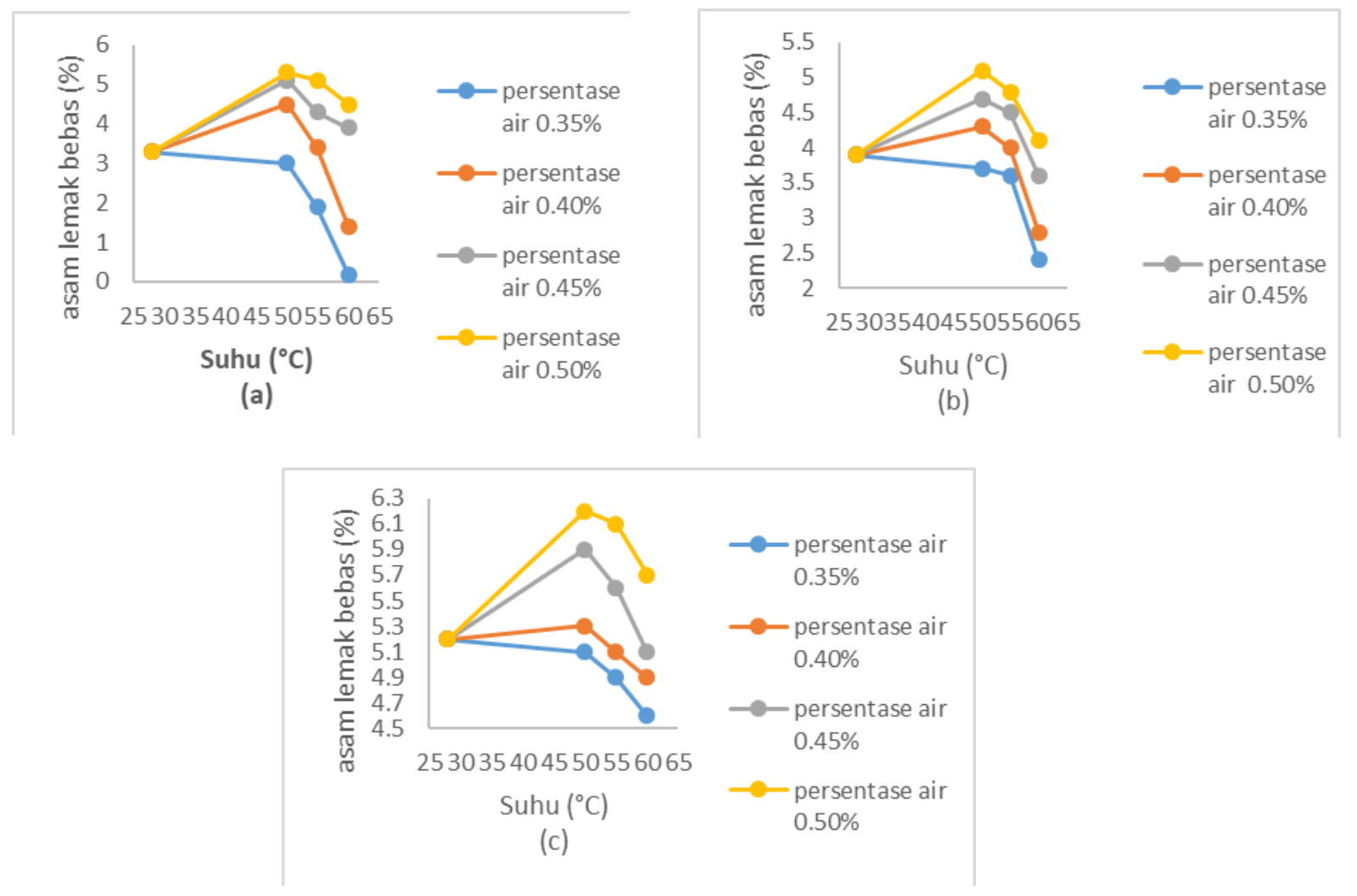

Gambar 3.1 Pengaruh Suhu Pemanasan dan Persentase Air Terhadap Asam Lemak Bebas (ALB) (a) Waktu Pemanasan Selama 8 Jam (b) Waktu Pemanasan Selama 16 Jam dan (c) Waktu Pemanasan Selama 24 Jam 
Hasil analisa pada gambar 3.1 (a), (b) dan (c) diatas dapat dilihat bahwa semakin rendah suhu pemanasan maka nilai asam lemak bebas (ALB) yang hasilkan juga semakin tinggi, dimana didalam grafik juga terlihat bahwa pada suhu $50^{\circ} \mathrm{C}$ menghasilkan rendemen yang paling tinggi. Sebaliknya semakin tinggi suhu pemanasan maka nilai asam lemak bebas (ALB) yang dihasilkan semakin rendah, dimana pada suhu $60^{\circ} \mathrm{C}$ menghasilkan rendemen paling rendah dalam waktu penyimpanan selama 8 jam yaitu dengan nilai asam lemak bebas (ALB) $4.5 \%$.

Secara umum suhu sangat berpengaruh pada reaksi kimia, dimana kenaikan suhu akan menaikkan kecepatan reaksi. Proses enzimatis pada dasarnya adalah serangkaian reaksi kimia sehingga kenaikan suhu akan meningkatkan kecepatan reaksi. Tetapi karena sifat enzim yang inaktif pada suhu tinggi, maka pada proses enzimatis ada batasan suhu supaya enzim dapat bekerja secara optimal (Toeti Herati Noerhadi, 1984).

Berdasarkan gambar 3.1 (a), (b) dan (c) dapat dilihat juga pada suhu $28^{\circ} \mathrm{C}$ asam lemak bebas (ALB) lebih rendah dibandingkan dengan suhu $50^{\circ} \mathrm{C}$, dikarenakan pada suhu $28^{\circ} \mathrm{C}$ tersebut menggunakan suhu ruang dan saat melakukan analisa juga tidak ada penambahan air dalam campuran minyak CPO, sehingga menghasilkan nilai asam lemak bebas (ALB) yang lebih rendah dibandingkan dengan suhu $50^{\circ} \mathrm{C}$. Dikarenakan air yang terkandung dalam minyak kelapa sawit itu sangat berpengaruh terhadap kenaikan asam lemak bebas (ALB).

Hasil analisa pada gambar 3.1 (a), (b) dan (c) terlihat bahwa persentase air juga berpengaruh besar dalam kenaikan asam lemak bebas (ALB), dimana semakin tinggi persentase air maka semakin tinggi nilai asam lemak bebas (ALB) yang dihasilkan, dimana dalam gambar 3.1 terlihat bahwa pada persentase air $0.50 \%$ menghasilkan nilai ALB tertinggi. Sebaliknya apabila semakin rendah persentase airnya maka semakin rendah pulalah nilai asam lemak bebas (ALB) yang dihasilkan, dimana dalam gambar 3.1 terlihat pada persentase air $0.35 \%$ terendah, dan pada persentase air $0.35 \%$ tersebut tidak ada penambahan air dalam menganalisa. 
Hasil analisa pada gambar 3.1 (a), (b) dan (c) yang diperoleh dalam waktu penyimpanan selama 8 jam dan 16 jam sudah sesuai dengan standar SNI yang mensyaratkan kadar asam lemak bebas (ALB) pada crude plam oil (CPO) maksimal 5.0\%. Sedangkan dalam waktu penyimpanan selama 24 jam sudah tidak sesui dengan standart mutu yang telah ditetapkan yaitu diatas 5.0\%. Dimana bahwa semakin lama waktu penyimpanan maka nilai asam lemak yang dihasilkan semakin tinggi.

\subsection{Pengaruh Suhu Pemanasan, Waktu Pemanasan, dan Persentase Air Terhadap Kadar Air}

Air dalam minyak terjadi karena proses salama sewaktu pembuahan dan akibat perlakuan di pabrik serta penimbunan. Kadar air (moisture) dalam minyak juga mempengaruhi kualitas atau mutu dari minyak tersebut (Yulianto, 2020). Kadar air dilakukan dengan menggunakan metode gravimetri (Kadar et al., 2009). Hasil penelitian terhadap kadar air yang dihasilkan dapat dilihat pada Gambar 3.2 (a),(b) dan (c) dibawah ini:

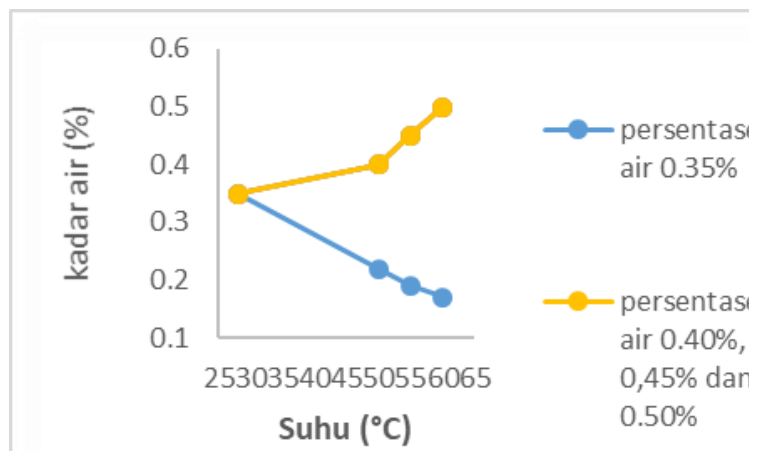

(a)

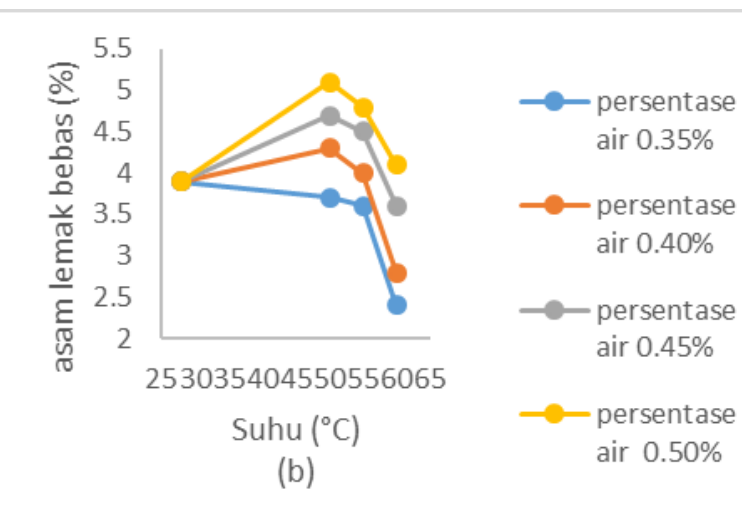




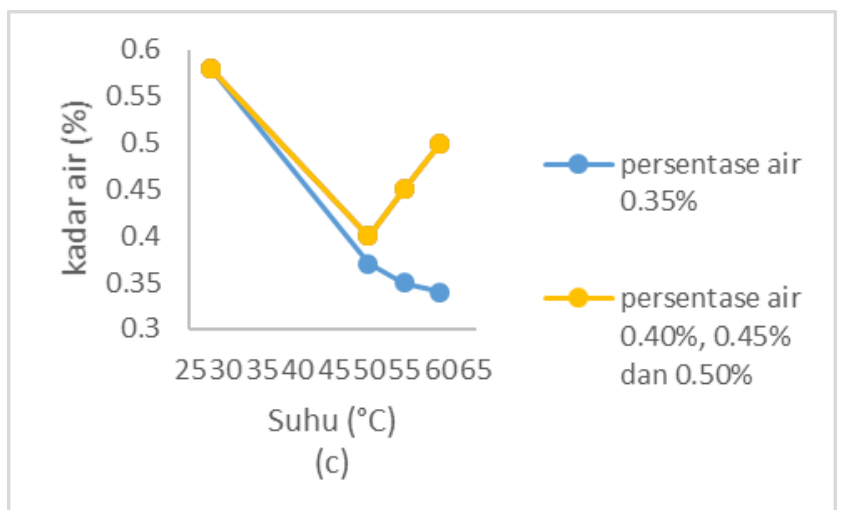

Gambar 3.2 Pengaruh Suhu Pemanasan dan Persentase Air Terhadap Kadar Air (a) Waktu Pemanasan Selama 8 Jam (b) Waktu Pemanasan Selama 16 Jam dan (c) Waktu Pemanasan Selama 24 Jam

Hasil analisa pada gambar 3.2 (a), (b) dan (c) diatas dapat dilihat bahwa semakin rendah suhu pemanasan maka nilai kadar air yang hasilkan juga semakin tinggi, dimana didalam grafik juga terlihat bahwa pada suhu $28^{\circ} \mathrm{C}$ menghasilkan rendemen yang paling tinggi. Sebaliknya semakin tinggi suhu pemanasan maka nilai kadar air yang dihasilkan semakin rendah, dimana pada suhu $60^{\circ} \mathrm{C}$ menghasilkan rendemen paling rendah dalam waktu penyimpanan selama 8 jam.

Secara umum suhu sangat berpengaruh pada reaksi kimia, dimana kenaikan suhu akan menaikkan kecepatan reaksi. Proses enzimatis pada dasarnya adalah serangkaian reaksi kimia sehingga kenaikan suhu akan meningkatkan kecepatan reaksi. Tetapi karena sifat enzim yang inaktif pada suhu tinggi, maka pada proses enzimatis ada batasan suhu supaya enzim dapat bekerja secara optimal (Toeti Herati Noerhadi, 1984).

Hasil analisa pada gambar 3.2 (a), (b) dan (c) terlihat bahwa persentase air juga berpengaruh besar dalam kenaikan kadar air, dimana semakin tinggi persentase air maka semakin tinggi nilai kadar air yang dihasilkan, dimana dalam gambar 3.2 terlihat bahwa pada persentase air $0.50 \%$ menghasilkan nilai kadar air tertinggi. Sebaliknya apabila semakin rendah persentase airnya maka semakin rendah pulalah nilai kadar air yang dihasilkan, dimana dalam gambar 3.2 terlihat pada persentase air $0.35 \%$ terendah, dan pada persentase air $0.35 \%$ tersebut tidak ada penambahan air dalam menganalisa. 
Kadar air adalah bahan yang menguap pada pemanasan dengan suhu dan waktu tertentu. Kadar air merupakan salah satu parameter untuk menentukan tingkat kemurnian minyak atau lemak dan berhubungan dengan daya simpannya, bau dan rasa. Kadar air sangat menentukan kualitas dari minyak atau lemak yang dihasilkan. Kadar air juga berperan dalam proses oksidasi maupun hidrolisis minyak yang akhirnya dapat menyebabkan ketengikan. Semakin tinggi kadar air, minyak akan semakin cepat tengik (Toeti Herati Noerhadi, 1984).

Berdasarkan gambar 3.2 (a), (b) dan (c) dapat dilihat juga pada persentase 0,35\% kadar air yang dihasilkan lebih rendah dikarenakan pada saat melakukan analisa tidak ada penambahan air dalam campuran minyak CPO, sehingga menghasilkan nilai kadar air yang lebih rendah dibandingkan dengan persentase yang lain. Dikarenakan air yang terkandung dalam minyak kelapa sawit itu sangat berpengaruh terhadap kenaikan asam lemak bebas (ALB).

Hasil analisa pada gambar 3.2 (a), (b) dan (c) yang diperoleh dalam waktu penyimpanan selama 8 jam dan 16 jam sudah sesuai dengan standar SNI yang mensyaratkan kadar air pada crude plam oil (CPO) maksimal 0.50\%. Sedangkan dalam waktu penyimpanan selama 24 jam sudah tidak sesuai dengan standart mutu yang telah ditetapkan yaitu diatas $0.50 \%$. Dimana bahwa semakin lama waktu penyimpanan maka nilai kadar air yang dihasilkan semakin tinggi.

\subsection{Hasil Analisa Asam Lemak Bebas (ALB) Pengaruh Waktu Penyimpanan dan Suhu Pemanasan \\ Asam lemak bebas (ALB) pada minyak Crude Palm Oil (CPO) yang} dilakukan dengan menggunakan metode titrasi asam basa (Kadar et al., 2009). Hasil penelitian yang dihasilkan dapat dilihat pada gambar 3.3. 


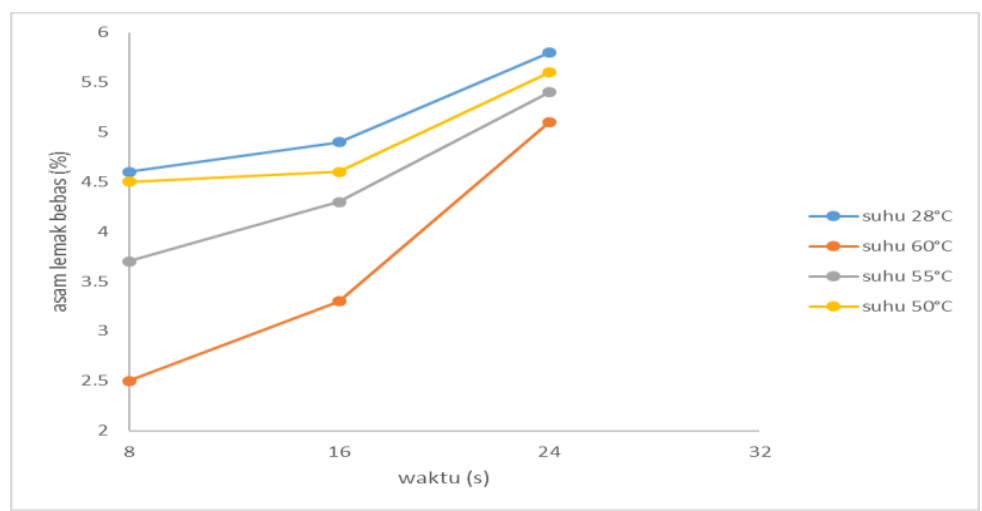

Gambar 3.3 Pengaruh Suhu Pemanasan dan Waktu Pemanasan Terhadap Asam Lemak Bebas (ALB)

Hasil analisa pada gambar 3.3 diatas dapat dilihat bahwa semakin turun suhu reaksi maka nilai asam lemak bebas (ALB) yang hasilkan juga semakin tinggi, dimana didalam grafik juga terlihat bahwa pada suhu $28^{\circ} \mathrm{C}$ menghasilkan rendemen yang paling tinggi. Begitu juga dengan semakin tinggi suhu reaksi maka nilai asam lemak bebas (ALB) yang dihasilkan semakin rendah, dimana pada suhu $60^{\circ} \mathrm{C}$ menghasilkan rendemen paling rendah dibandingkan dengan suhu-suhu yang lain yaitu dengan nilai asam lemak bebas (ALB) $2.5 \%$ pada penyimpanan 8 jam, 3.3\% pada penyimpanan 16 jam dan $5.1 \%$ pada penyimpanan 24 jam.

Secara umum suhu sangat berpengaruh pada reaksi kimia, dimana kenaikan suhu akan menaikkan kecepatan reaksi. Proses enzimatis pada dasarnya adalah serangkaian reaksi kimia sehingga kenaikan suhu akan meningkatkan kecepatan reaksi. Tetapi karena sifat enzim yang inaktif pada suhu tinggi, maka pada proses enzimatis ada batasan suhu supaya enzim dapat bekerja secara optimal (Toeti Herati Noerhadi, 1984).

Gambar 3.3 juga menjelaskan bahwa lama penyimpanan juga berpengaruh terhadap kenaikan asam lemak bebas (ALB), dimana semakin lama waktu pemanasan maka semakin tinggi nilai asam lemak bebas (ALB) yang dihasilkan, dalam gambar 3.3 terlihat bahwa dalam waktu 24 jam ALB yang dihasilkan lebih tinggi dibandingkan dengan waktu pemanasan selama 16 jam dan 8 jam.

Kenaikan kadar asam lemak bebas selama penyimpanan disebabkan proses hidrolisa, dimana pada proses hydrolisa akan mengkasilkan satu molekul gliserol 
dan tiga molekul asam lemak bebas. Air dan kotoran seperti protein pada minyak merupakan media yang baik bagi pertumbuhan mikroba. Mikroba tersebut akan memproduksi enzim yang mengakibatkan minyak terhidrolisa.

Hasil pada gambar 3.3 yang diperoleh dalam waktu penyimpanan selama 24 jam tidak sesuai dengan standar SNI yang mensyaratkan kadar asam lemak bebas (ALB) pada crude plam oil (CPO) maksimal 5.0\%.

\subsection{Hasil Analisa Kadar Air Pengaruh Waktu Penyimpanan dan Suhu Pemanasan}

Air dalam minyak terjadi karena proses selama waktu pembuahan dan akibat perlakuan dipabrik serta penimbunan. Kadar air dalam minyak juga mempengaruhi kualis atau mutu dari minyak tersebut (Yulianto, 2019). Kadar air dilakukan dengan menggunakan metode gravimetri (Kadar et al., 2009). Hasil penelitian yang dihasilkan dapat dilihat pada gambar 3.4 dibawah ini,

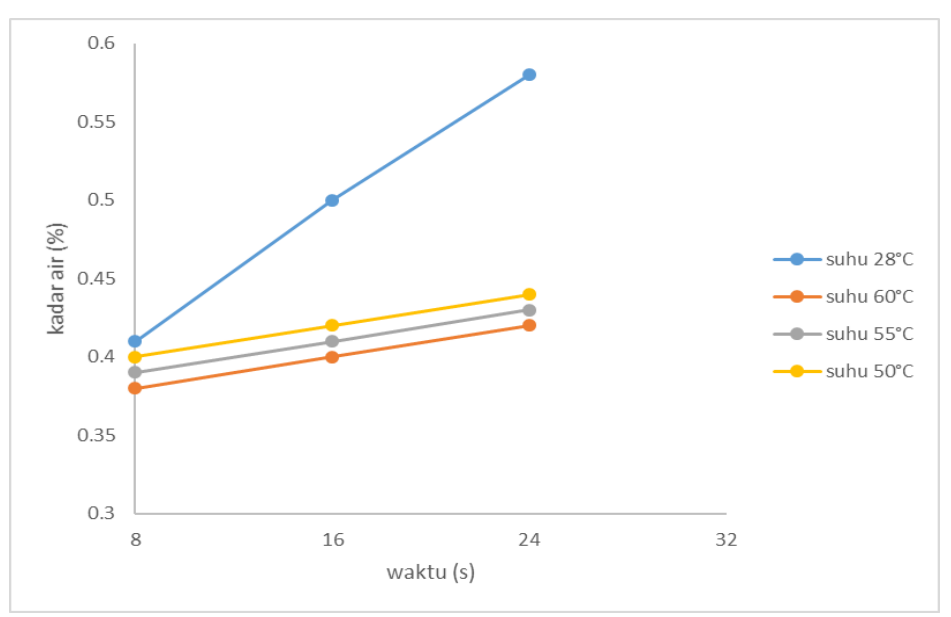

Gambar 3.4 Pengaruh Suhu Pemanasan dan Waktu Pemanasan Terhadap Kadar Air

Hasil analisa pada gambar 3.4 diatas sama hal nya dengan kadar asam lemak bebas yaitu dapat dilihat bahwa semakin turun suhu reaksi maka nilai kadar air yang hasilkan juga semakin tinggi, dimana didalam grafik juga terlihat bahwa pada suhu $28^{\circ} \mathrm{C}$ menghasilkan rendemen yang paling tinggi. Begitu dengan sebaliknya semakin tinggi suhu reaksi maka nilai kadar air yang dihasilkan semakin rendah, dimana pada suhu $60^{\circ} \mathrm{C}$ menghasilkan rendemen paling rendah dibandingkan dengan suhu - suhu yang lain yaitu dengan nilai kadar air $0.38 \%$ 
pada penyimpanan 8 jam, 0.4\% pada penyimpanan 16 jam dan $0.42 \%$ pada penyimpanan 24 jam.

Kadar air adalah bahan yang menguap pada pemanasan dengan suhu dan waktu tertentu. Kadar air merupakan salah satu parameter untuk menentukan tingkat kemurnian minyak atau lemak dan berhubungan dengan daya simpannya, baud an rasa. Kadar air sangat menentukan kualitas dari minyak atau lemak yang dihasilkan. Kadar air juga berperan dalam proses oksidari maupun hidrolisis minyak yang akhirnya dapat menyebabkan ketengikan. Semakin tinggi kadar air, minyak akan semakin cepat tengik (Toeti Herati Noerhadi, 1984).

Gambar 4.4 juga menjelaskan bahwa lama penyimpanan juga berpengaruh terhadap kenaikan kadar air, dimana semakin lama waktu pemanasan maka semakin tinggi nilai kadar air yang dihasilkan, dalam gambar 3.4 terlihat bahwa dalam waktu 24 jam kadar air yang dihasilkan lebih tinggi dibandingkan dengan waktu pemanasan selama 16 jam dan 8 jam.

Hasil pengukuran pengaruh lamanya waktu penyimpanan buah terhadap kadar air minyak sawit yang ditunjukan pada gambar 3.4. Gambar 3.4 menunjukan bahwa semakin lama waktu penyimpanan maka semakin meningkat kadar air minyak sawit yang dihasilkan. Kadar air yang tinggi dapat menyebabkan kerusakan pada CPO, hal ini terkait dengan reaksi hidrolisis yang terjadi yang dapat meningkatkan kadar asam lemak bebas pada minyak kelapa sawit. Reaksi ini akan dipercepat dengan adanya factor - factor panas, air, keasaman dan katalis (enzim) (Merle-Méjean et al., 1989).

Hasil yang diperoleh dalam waktu penyimpanan selama 24 jam pada suhu 28 tidak sesuai dengan standar SNI yang mensyaratkan kadar asam lemak bebas (ALB) pada crude plam oil (CPO) maksimal 0,5\%.

Hasil analisa yang dilakukan di laboratorium bahwa suhu pemanasan, waktu pemanasan dan persentase air itu sangat berpengaruh besar dalam kenaikan asam lemak bebas (ALB) dan kadar air yang dihasilkan. Dimana semakin tinggi suhu pemanasan maka nilai asam lemak bebas dan kadar air yang dihasilkan semakin rendah, dan sebaliknya apabila semakin rendah suhu pemanasan maka semakin tinggi pulalah nilai asam lemak bebas (ALB) dan kadar air yang 
dihasilkan. Lama pemanasan juga sangat berpengaruh dalam kenaikan asam lemak bebas (ALB) dan kadar air yang dihasilkan, dimana dalam waktu 24 jam kadar asam lemak bebas (ALB) dan kadar air yang dihasilkan melebihi standar mutu minyak kelapa sawit yang telah ditetapkan. Hasil analisa yang dipengaruhi oleh persentase air juga sangat berpengaruh besar terhadap kenaikan asam lemak bebas (ALB) dan kadar air dikarenakan adanya reaksi hidrolisa tersebut.

\section{Simpulan dan Saran}

Kesimpulan yang didapat dari penelitian ini adalah semakin rendah suhu pemanasan dalam minyak kelapa sawit maka semakin tinggi pula asam lemak bebas (ALB) dan kadar air yang dihasilkan. Semakin lama waktu penyimpanan minyak CPO maka kadar asam lemak bebas (ALB) dan kadar air yang dihasilkan juga semakin tinggi. Kadar asam lemak bebas (ALB) dan kadar air yang terbaik didapatkan pada lama penyimpanan selama 8 jam dengan suhu $60^{\circ} \mathrm{C}$. Hasil analisa yang dihasilkan persentase air sangat berpengaruh besar dalam kenaikan asam lemak bebas (ALB) dibandingkan dengan suhu pemanasan dan lama pemanasan dalam minyak kelapa sawit.

Adapun saran yang dapat diberikan dari hasil penelitian ini adalah diharapkan untuk penelitian selanjutnya dapat dilakukan variasi waktu pemanasan agar memperoleh hasil yang sesuai dengan standart mutu.

\section{Daftar Pustaka}

Ayu, D. F., Sormin, D. S., \& Rahmayuni. (2020). Jurnal Teknologi dan Industri Pertanian Indonesia. Jurusan Teknologi Hasil Pertanian, 12(02), 10-16.

Derlean, A. (2009). Pengaruh Suhu dan Lama Pemanasan terhadap Kerusakan Minyak Kelapa. Jurnal MIPA, Kependidikan Dan Terapan, 1(1), 19-26.

Dikti, V. (2016). 2,5) ,. 26(2), 207-215.

Ihsan, M., \& Adi, I. (2017). LAPORAN KERJA PRAKTIK LABORATORIUM PENURUNAN KADAR FFA ( FREE FATTY ACID) PADA PROSES ESTERIFIKASI UNTUK MENINGKATKAN KUALITAS.

Kadar, D. A. N., Di, K., Iii, P., \& Tinggi, T. (2009). Pengaruh Waktu Inap Cpo Pada Storage Tank Terhadap Kadar Asam Lemak Bebas , Kadar Air ,. 
Lembar, T. A. (2021). “ Hak Cipta Badan Standardisasi Nasional, Copy standar ini dibuat untuk penayangan di www.bsn.go.id dan tidak untuk di komersialkan " Lampiran A ( normatif) Lembar penilaian sensori terasi udang. 6.

Merle-Méjean, T., Bouchareb, S., \& Tranquille, M. (1989). Resonance Raman and infrared studies of matrix-isolated $\mathrm{Cu} 0$ (ethylene)n complexes. Contribution of C2H4/C2D4 mixture to the structural analysis. Journal of Physical Chemistry, 93(4), 1197-1203. https://doi.org/10.1021/j100341a009

Nasikin, M., \& Nurhayanti, S. W. (n.d.). Penggunaan Metode Netralisasi dan Pre-esterifikasi untuk Mengurangi Asam Lemak Bebas pada CPO (Crude Palm Oil ) dan Pengaruhnya terhadap Y ield Metilester.

Toeti Herati Noerhadi. (1984). Kualitas Manusia dalam Pembangunan. 2(November), 1-15.

Yulianto. (2020). Analisis Quality Control Mutu Minyak Kelapa Sawit Di Pt. Perkebunan Lembah Bhakti Aceh Singkil. Amina, 1(2), 72-78. https://doi.org/10.22373/amina.v1i2.36 